原著

\title{
Heavy-chain 病の肝生検組織所見 その光学䫓微鏡ならびに電子顕微鏡的観察について
}

\author{
岡山大学医学部第一内科 (主任 小坂淳夫教授) \\ 山田剛太郎 小林 敏成 幡 慶一 \\ 过孝夫 太田 康幸 小坂 淳夫
}

\section{LIGHT AND ELECTRON MICROSCOPIC OBSERVATIONS ON THE LIVER OF A CASE OF HEAVY-CHAIN DISEASE}

\author{
Gōtarō Yamada, Toshinari Kobayashi, Keiichi Hata, Takao Tsujı \\ Yasuyuki ŌTA and Kiyowo Kosaka
}

The First Department of Internal Medicine, Okayama University Medical School, Okayama

(Director: Prof. Kiyowo Kosaka)

\begin{abstract}
概要 本邦初例のheavy-chain病症例の腹腔鏡下肝生検により得た肝組織について光学顕徽鏡的, 電

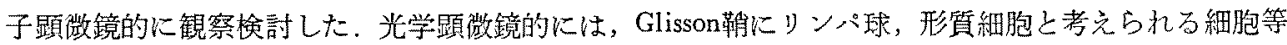
の軽度の浸潤が涊められるにすぎなかつた。電子顕微鏡的観察では, 肝寒質細胞は, 粗面小胞体が比 較的少なく，しかも，核の近くに限局して存在し，一方，グリコーダン顆粒が多く認められた。 Glisson鞘に浸潤している形質細胞之考えられた細胞は，よく発達したGolgi野と，層状配列を示す粗面小 胞体を有し，典型的な形質細胞として䘽察されたが，乙の粗面小胞体に付着しているpolysomeを檴成 しているribosomeを数党，その分布より，これらのpolysomeで合成されている蛋白質の分子量を算定 すると25,000〜30,000前後となり，本例のheavy-chain病蛋白の沈降保数 3.7 と合わせ考えて，肝内 に浸潤しているかかる細胞は，heavy-chain病蛋白を合成している細胞と断定した。
\end{abstract}

\section{緒言}

Heavy-chain 病は1964年にFranklin ${ }^{1)}$ が初め て報告して以来, 現在では本邦の3 例2334)を含め て，世界で少なくとも15余例占があるといわれて いる. heavy-chain病の臨床像では報告例の約半 数に肝腫大が認められているが，剖検例の肝組 織学的記載は 3 例 $\left.\left.{ }^{6}>7\right) 12\right)$, 肝生検例の報告は本例

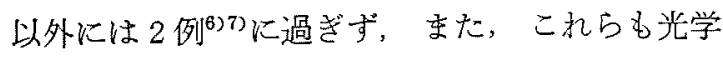
顕微鏡的観察にとどまつており，電子顕微鏡レベ ルによる検討は行なわれていない，著者らは，本 邦初例のheavy-chain病として迲らが詳しく報告 〔昭和 46 年 6 月 14 日受稿]
した ${ }^{27879)}$ 症例の腹腔鏡下に実施した肝生検により 得た肝組織を光学顕微鏡的, 電子顕微鏡的に観察 したので報告する。

\section{材料と方法}

症例は过ら ${ }^{288) 99}$ に上り臨床像, 臨木免疾反応, 免疫化学的検討などについて詳細な報告がなされ ているので簡単に記載する，36才の女性で，肝疾 患の既往歷は無いが，2 年前温のら炎を指摘さ れたことがある，入院時現症では，肝蔵は右鎖骨 中央線で 3 横指径触知，硬度は軟で表面は平滑で ある.脾藏は 1 横指径触知. 主要な検査成績は， Fig. 1 に示すと括りであるが，肝機能検查で 
Routin blood studies:

hemoglobin, $45 \% \quad$ RBC $270 \times 10^{4}$

WBC 2,300 with $9 \%$ segmented neutrophils, no cosinophil, no basophil, no plasma cell, $4 \%$ monocytes and $85 \%$ lymphocytes contained $5 \%$ atypical lymphocytes

platelet count, $12 \times 10^{4}$

Urinalysis :

$500 \mathrm{mg}$ of protein per day

Bence-Jones protein negative on five occations

Sternal bone marrow smears:

nucleated cells count 65,000

erythroid series $\quad 19.0 \%$

myeloid series $\quad 12.4 \%$

lymphocyte series $33.2 \%$

plasma cells $\quad 36.4 \%$

Serum proteins:

$\begin{array}{lll}3.6 \mathrm{~g} / \mathrm{dl} & \mathrm{A} / \mathrm{G} 0.49 & \\ \text { albumin 33\% } & \alpha_{1} \text {-globulin 4.5\% } & \alpha_{2} \text {-globulin } 4.5 \% \\ \beta \text {-globulin 3.5\% } & \gamma \text {-globulin 7\% } & \text { M-component 46\% }\end{array}$

Liver function tests :

total bilirubin $1.18 \mathrm{mg} / \mathrm{dl}$ (D. $0.49 \mathrm{mg} / \mathrm{dl}$ )

TTT $1 \mathrm{Mu}$ ZTT $2 \mathrm{Ku}$ CCF (-) Co $\mathrm{R}_{y}$

alk-P-ase $2 \mathrm{Bu}$ GOT $4 \mathrm{u} \quad$ GPT $2 \mathrm{u}$ cholesterol $98 \mathrm{mg} / \mathrm{dl}$

bromsulphalein retention $1.2 \%$ per 45 minutes

Xray exam. of skeletal system:

no characteristic myelomatous lesions

Fig. 1. Labolatory studies on admission.

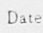

May '68

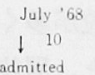

Aug. '68

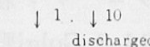

Treatmen

Peritneoscopy

Bloud Transfusion

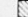

Laboratory studie:

Serum protein $(g / d)$

M-component $1 \%$

of serum protein

Plasma cell (

in myelogram

Physical examination

Liver (f.b.)

Spleen (f.b.)

Fig. 2. Hospital course

は総ビリルビン $1.18 \mathrm{mg} / \mathrm{dl}$ （直接型 $0.49 \mathrm{mg} / \mathrm{dl}$ ) とや や高く、コバルト反応 $R_{8} て ゙ ，$ 他の肝機能検査は 異常ない. 入院後経過はFig. 2 に示すごとく で，入院第15日目よりprednisolone 60mg/日の投与 を開始し，入院第22日目に腹腔鏡梌査を実施し た、腹腔鏡による観察では，肝右葉の著明な腫大 と脾腫以外には異常所見を得ることができなかつ た。

腹腔鏡直視下で肝右葉の生㭘により得た肝組織
片を，光学顕微鏡用にはアルコール性Bouin液で 固定, パラフィン切片をへマトキシリン・エオジ ン染色, マロリー・アザン染色, 過ヨウ素酸シッ ク染色, Pap鍍銀染色, ベルリンブルー反応鉄染 色，打よびメチル緑・ピロニン染色を施し検討し た。電子顕微鏡用には，朋組織片を0.1规定燐 酸緩衝液（pH 7.2〜 7.4）を用いて調整した. $6.25 \%$ グルタールアルデヒド $\left.{ }^{10}\right)$ で水室 $\left(4{ }^{\circ} \mathrm{C}\right)$ に て 2 時間固定し, 固定後 $1 \mathrm{ml}$ につ $0.058 \mathrm{~g}$ の蔗 糖を加えて等張とした同緩衝液で水洗し，さらに $1 \%$ オスミウム酸固定液（ 0.1 規定 $\mathrm{pH} 7.2 \sim 7.4$ 燐酸㣪衝液 $1 \mathrm{ml}$ につき $0.045 \mathrm{~g}$ の蔗糖を加兄等張 とした））で，同様に氷室で 2 時間再固定し，前 記等張緩衝液にて水洗後エタノール系列により脱 水し，Epon 812に包埋した. 包埋試料をJUM-5A 型ultramicrotomeでガラスナイフを用い，超薄切 片を作製し， $3 \%$ 酶酸ウラニールおよび水酸化鉛 で二重染色を施し，HS-8 型, 拈よびHU-11型電 子䫒微鏡で観察し, 直接倍率 3,000 9,000倍で 写真撮影した.

\section{成 績}

光学顕微鏡的観察ではGlisson鞘に軽度の細胞浸 潤がみられ，その浸潤細胞は主としてリンパ球で あるが，車輪状の核を有し，胞体が好塩基性を 示す形質細胞と考克られる細胞も混在していた。 また，細胆管がごく軽度に增殖して見られた，小 葉内部では, 肝実質細胞の胞体は明るくリポフス チン顆粒も比較的多く認められた。類洞には， Glisson䩗に和けると同様な少数の単核細胞の浸潤 がみられたが， Kupffer細胞の腫大・增殖は目立 たなかつた (Fig. 3)，メチル緑・ピロニン染色 では，核小体と同時に核周囲に限局した細胞質の 部分がピロニン陽性を示す肝細胞が多く観察され た，Glisson䩪や類洞には，車輸状の核を有し細胞 質がび漫性にピロニン好性を示す細胞と同時に， 核はリンパ球に類似するが胞体がやや広くピロニ ン陽性物質を細胞質内に有する細胞が散見された (Fig. 4).

電子顕微鏡的観察では，肝実質細胞は核飞著変 


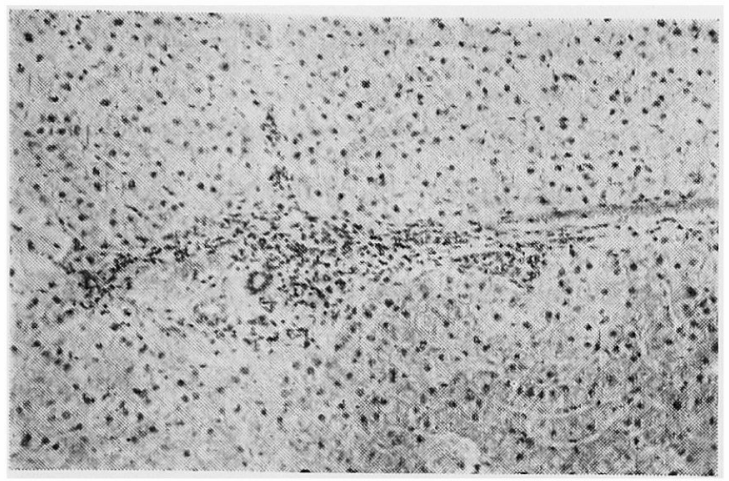

1

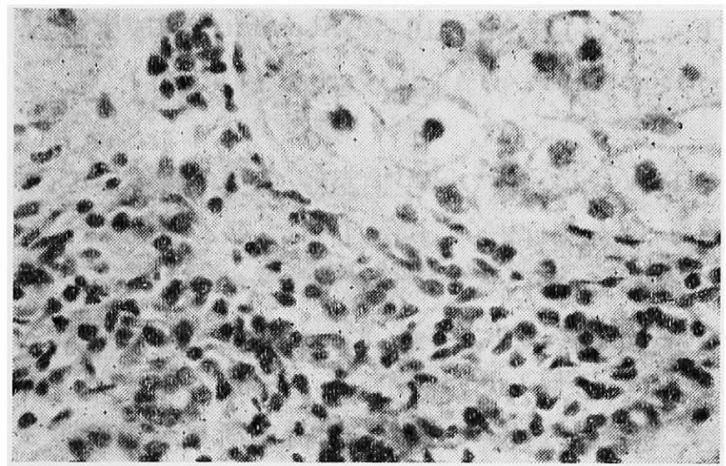

2

Fig. 3. A mild cellular infiltrate and slightly proliferated bile ducts in a portal tract. Cytoplasm of hepatic parenchymal cells are pale. $\mathrm{H} \& \mathrm{E}, 1$ ) $\times 50,2) \times 200$

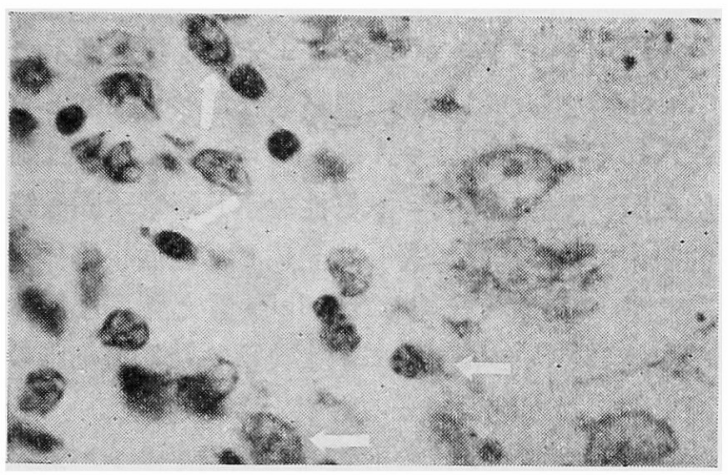

Fig. 4. Arrows show methyl green-pyronin-positivecells infiltrating in a portal tract. In hepatic parenchymal cells there are methyl green-pyronin-positive granules around the nucleus. Methyl green-Pyronin. $\times 1000$

なく，細胞質ではグリコーゲン顆粒がび漫性に増 加し, 粗面小胞体は減少し, かつ核付近に限局し て観察された．系粒体は $1 \mu$ 前後の円形のもの が汇とんどで形態異常は認められなかつた（Fig.

6). Golgi野はほぼ正常で，毛細胆管にも異常な く、リポフスチン顆粒がやや多く認められた (Fig，7)，類洞上皮細胞は形態上異常なく， Kupffer細胞には吞食像以外に異常所見は認めな かつた，類洞やGlisson鞘に浸潤している細胞では 多く成熟したリンパ球の形態を認めたが，これら に混在して, 成熟リンパ球に比較して胞体が広く, 糸粒体が多く，遊離ribosomeppolysomeの多いリ ンパ球 (Fig. 9) もかなり多く認められた。

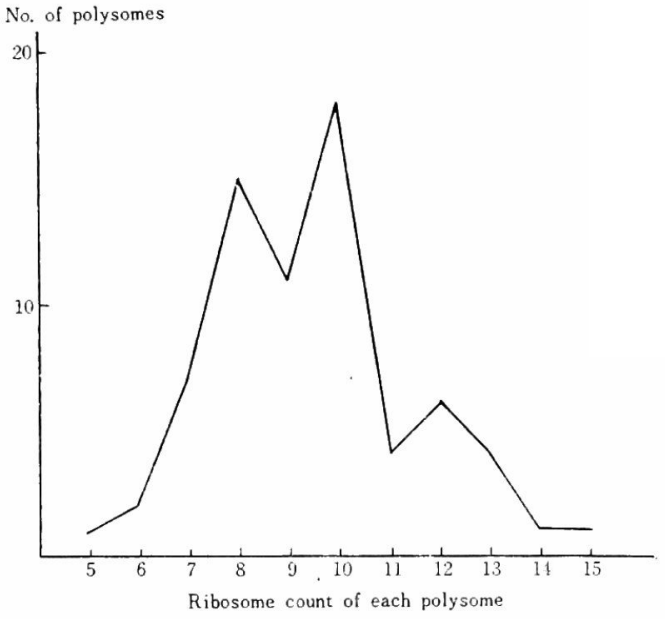

Fig. 5. Ribosome count of each polysome observed on the endoplasmic reticulum of plasma cells in the liver.

また，光学顕微鏡で形質細胞と診定した 細胞 は，核膜および細胞表面膜に平行して著明な層状 配列を示し，その内腔が一部で拡大している粗面 小胞体を有するが，同時によく発達したGolgi野 が認められた（Fig. 8，10）。この細胞には細胞 質内結晶, 核内封入体, ビールス粒子等は認める ことができなかつた。ささらに，Petris ${ }^{11)}$ 方法に 従つて, この細胞について粗面小胞体の表面が超 薄切片に平行ないしは，ななめに切れている部分 のpolysome75個を選んで，それぞれのpolysome を構成しているribosomeの数を算定してみると 
(Fig. 11，12)，8〜10個のribosomeで構成される polysomeにピークが認められた (Fig. 5).

\section{考 察}

Heavy-chain病の肝生検組織の 光学䡛微鏡的観 察は, 第 5 例目 ${ }^{6}$ ，第 6 例目 ${ }^{7}$ 牤よび本症例飞つい て行なわれているが，詳細な報告はないすななる ๖, 5 例目ではりンパ球,形質細胞拉よび細網細胞 の小さな限局した浸潤がみられる以外に肝実質細 胞に著変はなく，6 例目では異常所見が得られて いない，剖検例に扣ける肝組織像の記載は，第 2 例目 $^{6)}, 6$ 例目 ${ }^{7)}, 8$ 例目 ${ }^{12}$ でみられ，いずれ子光 学顕微鏡的観察であるが，2 例目で形質細胞，細 網細胞，リンパ球，好酸球の浸潤が認められて拉 り，6例目では悪性細網細胞の浸潤が認められて いるが形質細胞の浸潤は認められていない８例 目に和いても形質細胞の浸潤はなく、へモジデリ ソのKupffer細胞等への沈着が認められているに 過ざない，本症例の肝生検組織でも，光学顕微鏡 的観察では，Glisson鞘や類洞にりンパ球および形 質細胞と考えられる細胞の浸潤が軽度に認められ たに過ぎない，電子顕微鏡的にも以下に考察を加 无変化以外に特に肝細胞, 内皮細胞, Kupffer 細胞に変化は見いたせなかつた。

ヘマトキシリン・エオシン染色標本で, 肝実質 細胞が明るくみ党た所見は, 肝細胞のグリコーゲ ン顆粒が増加していることを推定せしめたが，こ れは同組織の電子顕徽鏡的観察で肝実質細胞内に グリコーゲン顆粒が增加していた所見からも裏づ けられた。グリコーゲン顆粒が肝細胞内で増加し ていた所見は，肝生検時，すでに治療として総 計 680mg prednisoloneを投与していたことから， glucocorticoidによるグリコーゲンの肝内貯留と 考えられた。 また，メチル緑・ピロニン染色標本 でピロニン陽性物質が肝細胞核周囲に限局して認 められた像は，電子顕微鏡的観察で肝細胞の粗面 小胞体が核周囲に限局して認められた所見と一致 した。しかし，かかる所見が本症に特有のもので あるか，あるいは単にグリコーゲン顆粒の増加に よる二次的な所見であるかは明らかでない。
電子顕微鏡的にGlisson䩗や類洞に比較的多く認 められた，成熟りンパ球とは異なるりンパ球，な なわち，一般のリンパ球と比較して細胞質の幅が 広く，かつ采粒体や，遊離ribosome, polysomeの 多いリンパ球は，メチル緑・ピロニン染色標本 で，核はリンパ球と類似するが胞体がやや広くピ ロニン陽性物質を細胞質内に有する細胞として観 察された細胞と一致するものであるう。かかる細

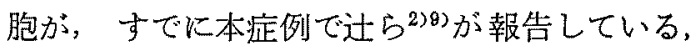
末梢血に $5 \%$ 出現し，から蛍光抗体法でその細胞 質内に $\gamma$ 鎖の局在を証明した異型りンパ球と同様 の細胞であるかどらかは興味ある問題であるが， 今後の研究に譲りたい.

次に，へマトキシリン・エオジン染色標本で Glisson鞘ならびに類洞に観察された形質細胞と考 えられる細胞は，メチル緑・ピロニン染色では細 胞質がび漫性にピロニン好性を示し，電子顕微鏡 的钼察では，層状に著しく発達した根面小胞体を 有し， かつよく発達したGolgi装置と粗面小胞体 の内空の拡大を局所的に示寸典型的な形質細胞の 像を備劣た細胞と同一のものと考えられた。

色疫グロブリンは，形質球系細胞やリンパ球系 細胞で，そのmRNAの鎖で結び合わされたpolysome上で合成されるといら ${ }^{13)}$ 。すなわら, Shapi$\mathrm{ro}^{14)}$, Williamson ${ }^{152}$ らはマウスの形質細胞腫の腫 瘍細胞を，Becker ${ }^{16)} ら は$ 免疫されたラットのリン パ節や脾蔵を利用して，それらのホモジネートか ら得られた抽出液の密度勾配超遠心法で，180〜 $190 \mathrm{~S}$ 前後にピークのある polysome と 270 300 S 前後にピークのあるpolysomeを認め，その電子影 微鏡的観察加ら $190 \mathrm{~S}$ 前後のpolysomeは $5 \sim 8$ 個 のribosomeで, $270 \mathrm{~S}$ 前後のpolysomeは 12〜20個 のribosomeで棈成ざれていることを形態学的に明 らかにしている。 さらに，へモグロビンの蛋白生 合成漈して分子量約17,0000polypeptideは，主 として 5 個のribosomeで構成される polysomeで合

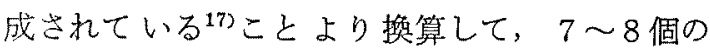
ribosomeよりなるpolysomeは分子量 25,000 前後の polypeptideを，16〜20個のribosomeよりなるpolyー 

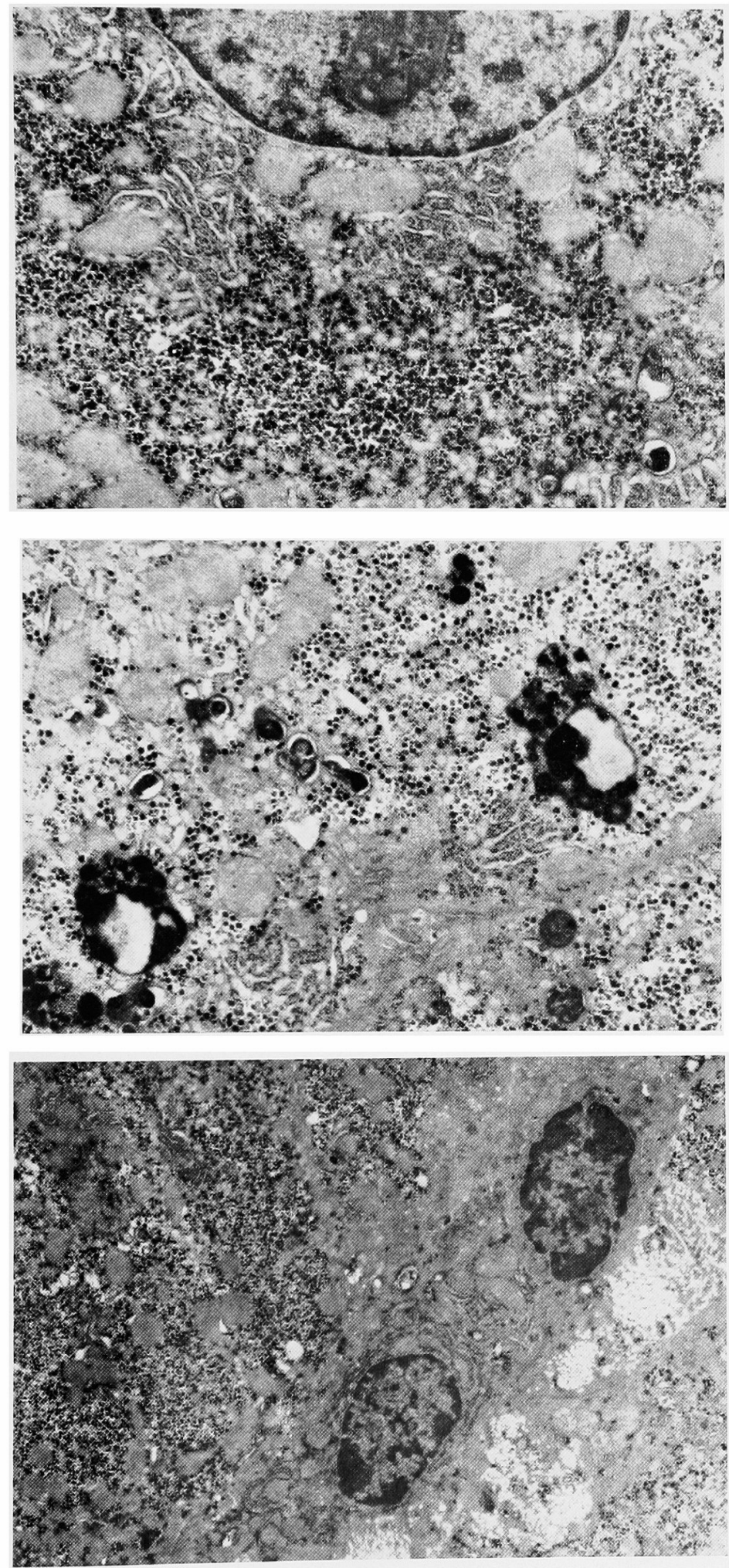

昭和 46 年 8 月 10 日

( 21$)$
Fig. 6. The central region of a hepatic parenchymal cell. Nucleus and nucleolus appear normal. The glycogen particles are diffusely dispersed and the rough-surfaced endoplasmic reticulums are decreased and found in the perinuclear area. $\times 6,000$

Fig. 7. Pericanalicular region. A bile capillary and Golgi complex are normal. Lipofuscin pigments are slightly increased. $\times 6,000$

Fig. 8. Sinusoid and the space of Disse. A plasma cell and a mature lymphocyte are present in the sinusoid. $\times 3,700$ 

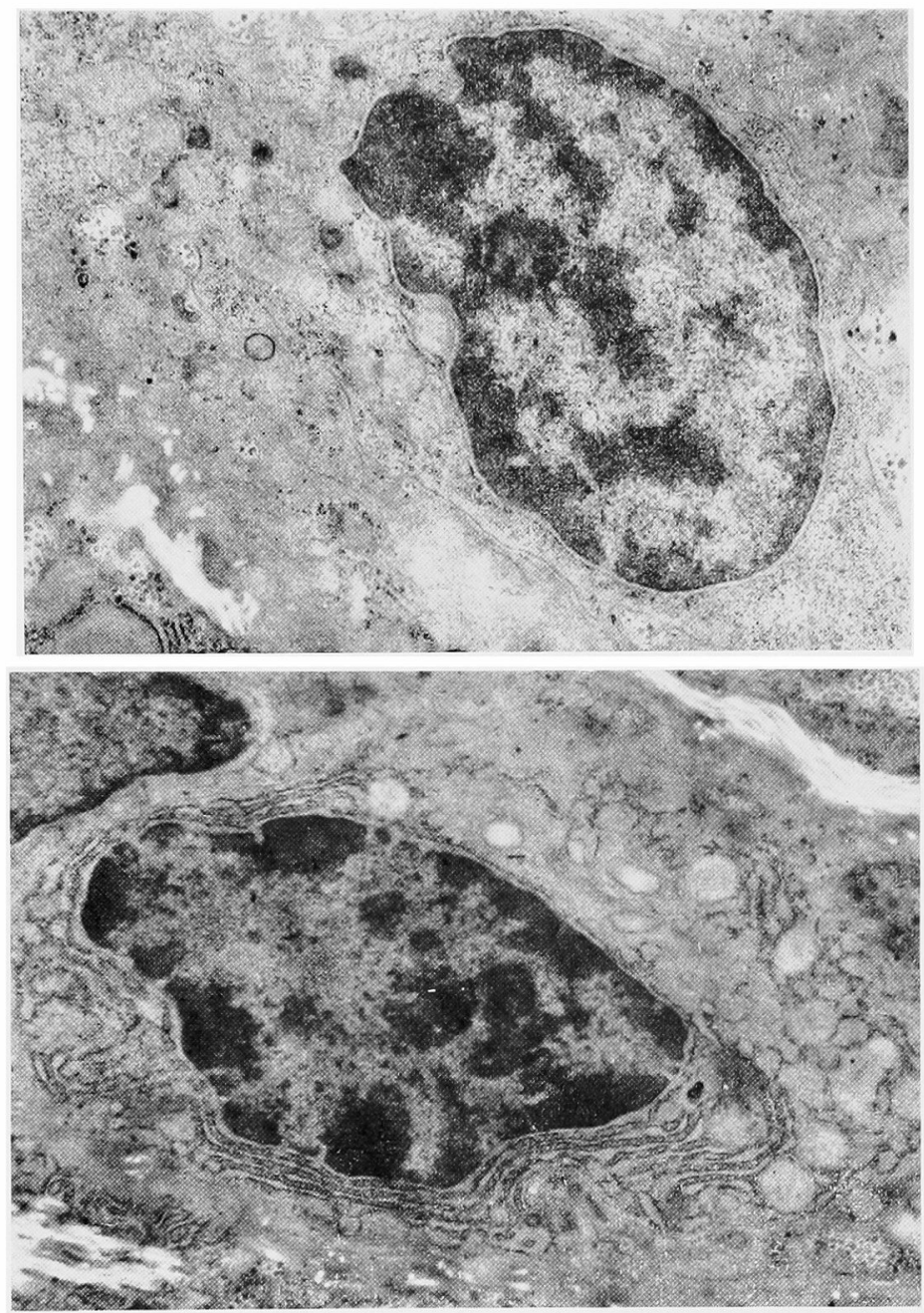

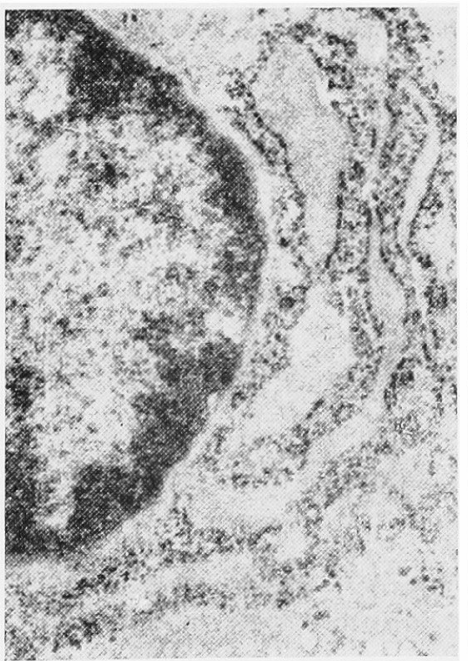

Fig. 11

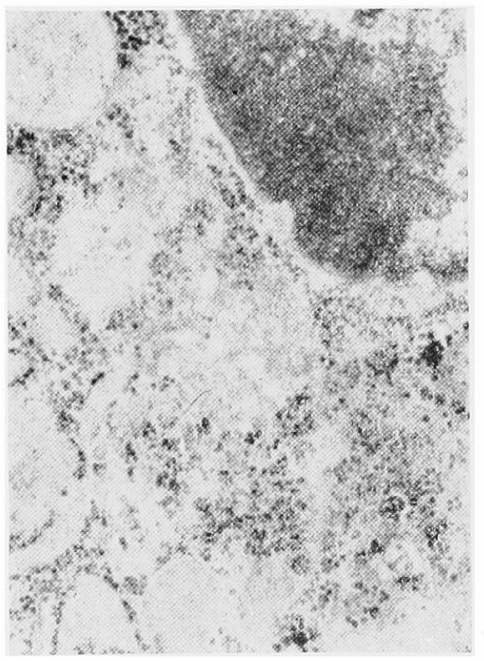

Fig. 12
Fig. 9. A lymphocyte in the sinusoid. The cytoplasm is wide. Abundant mitochondria, free ribosomes and polysomes as compared with those in mature lymphocyte, are contained in this lymphocyte. $\times 8,600$

Fig. 10. A plasma cell in the sinusoid contains well developed lamellar rough-surfaced endoplasmic reticulum and the conspicuous Golgi complex. $\times 8,600$
Fig. 11 \& Fig. 12. Large magnification of a plasma cell. Membrane-bound polysomes composed of 8 to 10 ribosomes are abundant. $\times 17,200$ 
someは 分子量 $55,000 \sim 60,000$ 前後の polypeptide を合成していることになり，これらはそれぞれ免 疫グロブリンのL鎖・H鎖の 1 本のpolypeptideの 分子量にほぼ相当することを記載している．さら に, Petris ${ }^{11)}$ はマウスの皮下の形質細胞腫を電子 顕微鏡的に観察し，腫瘍細胞の粗面小胞体上の polysomeが10〜16個のribosomeからなる大きな polysomeと6〜8 個のribosomeからなる小さな polysomeよりなることを超薄切片上で認め，それ ぞれIgG骨髄腫のL鎖・H鎖を生成するmRNAを 有しているpolysomeであららと推测している。

そこで，著者らは粗面小胞体の表面に付着した polysomeは分泌性の蛋白を 合成しているとのCampbellら ${ }^{18)}$ の考光に基ういて，粗面小胞体に付着 しているpolysomeを構成しているribosomeの数が わかれば，そのpolysomeでつくられるpolypeptide の分子量をある程度知ることができ，また，ribosomeの直径が $200 \AA$ 前後であり, mRNA上のribosomeの間隔は50〜 $100 \AA$ 前後であることより, polysomeが何個のribosomeで構成されているかが わかれば，そのpolysome上のmRNAの長さを知る ことができ，さらに，mRNA上のnucleotideの間

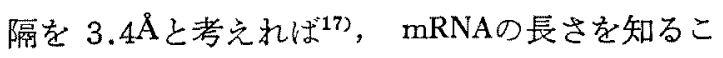
とにより，産生される蛋白質のアミ！酸の数もほ ぼ推定できると考兑，本症例の肝組織で観察され た形質細胞と考兄られる細胞の粗面小胞体上の polysomeについて検討した，その結果，8１0個の ribosomeで構成される polysomeの分布にピーク が認められ (Fig. 5)， mRNAの長さは 2,500A 前後で，200〜 250個のアミ，酸よりなる分子量 25,000〜30,000前後のpolypeptideを合成している ものと断定しえた。 ところで，过が，すでに報告 している゙本症例の血清および尿から得られた heavy-chain病蛋白の超遠心に上る沈降係数は3.7 Sであり，現在までに報告されている他の症例 のheavy-chain病蛋白の超遠心による沈降係数は $3.0 \sim 4.1 \mathrm{~S}$ の間であり, 55,000前後 ${ }^{1193}$ の分子 量に相当する. heavy-chain病蛋白はdimer型と考 えられている1ので，沈降係数より算定した本例 のheavy-chain病㔻白の 1 本 Deptide鎖の分子量 も泳ぼ25,000〜30,000前後となり, 電子顕微鏡的 に観察されたpolysomeで合成される蛋白の分子量 にほぼ一致した。 また著者らが提供した胸骨骨䯣 穿刺の材料より、木谷ら ${ }^{20)}$ が形態学的に骨㖪腫細 胞の特徵を備えている細胞の粗面小胞体に付着し ているpolysomeを構成するribosomeについて同様 に検討した結果とも，ほほ一致した，従つて，電 子顕微鏡的に形質細胞としての形態を有する細胞 は, heavy-chain病蛋白を合成している細胞と考 点られ，この種の細胞が, 肝藏のGlisson鞘にも浸 潤していることが判明した。

\section{結 論}

本邦第 1 例目のHeavy-chain病の症例について, 腹妿鏡下に実施した肝生検により得た組織を光学 影微鏡的ならびに電子顕溦鏡的に検討し，以下の 結論を得た。

1）肝実質細胞は，光学顕微鏡的にリポフスチ ン顆粒を比較的多く認める以外にとくに異常所見 は認められなかつた，電子顕微鏡的には，核，細 胞質内小器管および毛細胆管に形態上の異常は認 められなからたが，粗面小胞体が比較的少なく， しかも核の近くに限局して存在した，一方，グリ コーゲン顆粒が多く，グリューゲン野が広く認め られたことは，治療のため使用したprednisolone によるグリコーゲンの肝細胞内への貯留によるも のと考兄られた，電子顕微鏡的観察でも，類洞上 皮細胞, Kupffer細胞に 異常所見は認められなか つた.

2）Glisson鞘および類洞には, 光学顕微鏡的に 軽度のリンパ球と形質細胞と考えられた細胞の浸 潤が認められた。電子顕微鏡的観察では，成熟り ソパ球に混在して胞体が広く, 系粶体が比較的多 く,遊離ribosome, polysomeの多いリンパ球が認め られた。かかりンパ球が过らの報告した末梢血 の異型リンパ球と同一のものかどらかは更に検討 を要する。形質細胞と考兄られた細胞は，電子影微 鏡的に著しく発達した湢状配列を示す粗面小胞体 を有する典型的な形質細胞として観察されたが， 
よく発達したGolgi野と一部の 粗面小胞体でその 䏺の拡大を認めた。かかる細胞内の粗面小胞体に 付着しているpolysomeを構成しているribosomeは $8 \sim 10$ 個で構成されており, polysomeのmRNAの 長さは $2500 \AA$ 前後で, $200 \sim 250$ 個前後のアミノ酸 よりなる分子量 $25,000 \sim 30,000$ 前後のpolypeptide を合成していることが推測され，本例のHeavychain病蛋白の沈降係数 $3.7 \mathrm{~S}$ であることと合わ せ考光て，肝内に浸潤しているかかる細胞は， heavy-chain病蛋白を合成している細胞と考えら れた。

\section{文献}

1) Franklin, E.C., Lowenstein, J., Bigelow, B. and Meltzer, M.: Heavy chain disease-a new disorder of serum-globulins. Amer. J. Med., 37: 332, 1964. 一2) 过孝夫他: Heavy-chain(Fc fragment) 病の 1 症例一本邦第 1 例目の症例化ついて一。 日内 会誌, $58: 1202,1969$. 一3) 今井幸雄, 向島達, 木 村禇代二：Heavy chain 病の 1 例（抄), 日血会誌, $32: 814,1969$. 一4) 安達原蜸司, 高踩隆一, 小出 紀, 松橋直: Toxoplasma 感作血球凝集反広で異常 を認めた Fc-fragment disease の 1 例. 第12回臨床 血液病学会総会, $1970 .-5$ ) 小坂淳夫, 辻孝夫 : 免疫グロブリン病一Heavy-chain病, 医学書院, 東 京, 1971印刷中. -6) Osserman, E.F. and Takatsuki, K.: Clinical and immunological studies of four cases of heavy $\left(\mathrm{H}_{2}\right)$ chain disease, Amer. J. Med., 37: 351, 1964. -7) Leberton, J. P., Rivat, C., Rivat, L., Profit, P., Guillemot, L. et Repartz, C.: Une immunoglobulinopathie meconnue: La maladie des chaines lourdes, Presse med., 75: 2251，1967. 一8）小坂淳夫, 太田康幸, 辻 孝夫, 宮本千鹤子: Heavy-chain病の 1 症例,
臨涼免疫, 1:57, 1969. 一9) Tsuji T.: Heavychain ( $\mathrm{Fc}$ frgament) disease-immunological reactions of the first case in Japan and the incorporation of c-amino acids into the protein in vitro, Acta. Haema. Jap., 33: 89, 1970. - 10) Sabatini, D.D., Bensch, K. and Barnett, R.J.: Cytochemistry and electron microscopy, The preservation of cellular ultrastructure and enzymatic activity by aldehyde fixation, J. Cell Biol., 17: 19, 1963. -11) Petris, S.: Polyribosomes in thin sections of 5563 plasmacytoma cells, J. Mol. Biol., 23: 215, 1967. -12) Zawadzki, Z., Benedek, T.G. Ein, D. and Easton, J.M.: Rheumatoid arthritis terminating in heavy-chain disease, Ann. Int. Med., 70: 335, $1969 . \quad$-13) Kabat, E.A.: Structural concepts in immunology and immunochemistry, 310, Holt, Rinehart and Winston, Inc., New York, 1968. -14) Shapiro, A.L., Scharff, M.D., Dazei, J.V. and Uhr, J. W.: Polyribosomes synthesizing heavy and light chains, J. Mol. Biol., 56: 216, $1966 . \quad$-15) Williamson, A.R. and Askonas, B.A.: Biosynthesis of immunoglobulins: The separate classes of polyribosomes synthesizing heavy and light chains, J. Mol. Biol., 23: 201, 1967. -16) Becker, M.J. and Rich, A.: Polyribosomes of tissues producing antibodies. Nature, 212: 142, $1966 . \quad$-17) Warner, J.R., Rich, A. and Holl, C.E.: Electron microscope studies of ribosomal clusters synthesizing hemoglobin, Science, 128: 1399, $1962 . \quad$-18) Campbell, P.N., Lowe, E. and Sharp M.: The morphorogical origin and function of the polysomes isolated from rat liver, Biochem. J., 99, 22C, 1966. 19) Ein, D., Bnell, D.E. and Fahey, J.L.: Biosynthetic and structural studies of a heavy chain disease protein, J. clin. Invest., 48: 785, 1969.

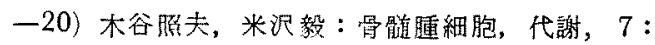
9 巻（䉓子顕微鏡シリーズ），1970. 